Funding: None; Competing interests: None stated.

\section{REFERENCES}

1. Sohn M, Ahn Y, Lee S. Assessment of primitive reflexes in high-risk newborns. J Clin Med Res. 2011;3:285-90.

2. Zafeiriou DI. Primitive reflexes and postural reactions in the neurodevelopmental examination. Pediatr Neurol. 2004; 31:1-8.

3. Nair MKC, Russell P. Illingworth's The development of the infant and young child: Normal and abnormal, Tenth edition. New Delhi: Elsevier; 2012.
4. Prechtl H. The neurological examination of the full-term newborn infant. In: Clinics In Developmental Medicine, Vol. 63, $2^{\text {nd }} e d$. Spastics International Medical Publications; 1977.

5. Ronnqvist L, Hopkins B, Van Emmerik R, De Groot L. Lateral biases in head turning and the Moro response in the human newborn: are they both vestibular in origin? Dev Psychobiol.1998;33:339-49.

6. Ronnqvist L. A critical examination of the Moro response in newborn infants - symmetry, state relation, underlying mechanisms. Neuropsychologia. 1995;33:713-26.

\title{
Bone Metabolism in Cow Milk Allergic Children
}

Children with cow milk allergy are suspected to develop calcium metabolism disturbances. We observed increased markers of bone turnover in these children. Children with cow milk allergy are more prone to develop the disturbances of the bone mineralization even in the first year of life.

Kew words: Bone metabolism, Children, Cow milk allergy.

$\mathrm{H}$ uman and cow milk contains several factors active in the regulation of bone metabolism and mineralization of the growing skeleton. Children with cow milk allergy (CMA) are under a potential risk of eating insufficient quantity of calcium in the diet [1]. We aimed to analyze the markers of bone mineralization and metabolism through an observational study. Our studied group consisted of 25 CMA children (aged $8 \pm 4.2$ months) and 65 healthy

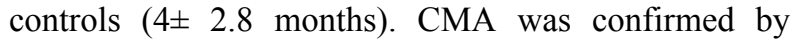
standardized open oral food challenge [2]. Enrolled children were fed with extensively hydrolyzed or amino acid formulas. The duration of milk-free diet was $4 \pm 0.26$ months. Vitamin D was administered to all the children from second week of life (666 I.U of cholecalciferol per day). The markers of bone metabolisms and turnover were analyzed from the serum and urine. The study was approved by the Ethical Committee.

In the control group of healthy children, all the examined parameters were within physiological ranges. Conversely, cow milk-allergic children showed lower serum and urine concentration of calcium (serum: $2.06 \pm 0.06$ vs. $2.26 \pm 0.03 \mathrm{mmol} / \mathrm{L}, P=0.008$; urine: $0.36 \pm 0.30 \quad$ vs. $\quad 1.51 \pm 0.68 \quad \mathrm{mmol} / \mathrm{kg} /$ day, $P=0.008)$. Alkaline phosphatase (ALP) and its bone isoform (BALP), the two markers of increased bone turnover, were significantly increased in children with CMA (ALP: $9.07 \pm 0.59 \mu \mathrm{kat} / \mathrm{L} v s .4 .04 \pm 0.42 \mu \mathrm{kat} / \mathrm{L}, P=0.008$; BALP: $87.67 \pm 3.88 \%$ of total serum ALP vs. $61.80 \pm 11.73 \%$ of total serum ALP, $P<0.001)$. Serum osteocalcin and urine hydroxyproline did not differ between the two groups.

We found enhanced bone turnover in cow milk allergic children compared to healthy infants during the first year of life. Patients with cow milk allergy are at potential risk for osteopenia because their milk-free diet usually contains low calcium contents [3]. Appropriate substitution of essential minerals into the diet of cowmilk allergic children could result in complete resolution of the clinical symptoms of osteopenia and rickets [4].

Acknowledgement: This work was supported by project "Center of Experimental And Clinical Respirology I" cofinanced from EU sources - European Regional Development Fund.

Lubica Jakusova, Milos Jesenak, Jela Schudichova ANd Peter Banovcin Centre for Treatment of Refractory Allergic Diseases in Children, Department of Paediatrics JFMCU, Kollarova 2,03659Martin, Slovakia; jesenak@gmail.com

\section{REFERENCES}

1. Jensen VB, Jorgensen IM, Rasmussen KB, Molgaard C, Prahl P. Bone mieral status in children with cow milk allergy. Pediatr Allergy Immunol. 2004; 15:562-5.

2. Saarinen KM, Juntunen-Backman K, Jarvenpaa AL, Kuitunen P, Lope L, Renlund M, et al. Supplementary feeding in maternity hospital and the risk of cow's milk allergy: A prospective study of 6209 infants. J Allergy Clin Immunol. 1999;104:457-61.

3. Tuokkola J, Kaila M, Kronberg-Kippila C, Sinkko HK, Klaukka T, Pietinen $\mathrm{P}$, et al. Cow's milk allergy in children: adherence to a therapeutic elimination diet and reintroduction of milk into the diet. Eur J Clin Nutr. 2010;64:1080-5.

4. Yu JW, Pekeles G, Legault L, McCusker CT. Milk allergy and vitamin $\mathrm{D}$ deficiency rickets: a common disorder associated with an uncommon diseases. Ann Allergy Asthma Immunol. 2006;96:615-9. 